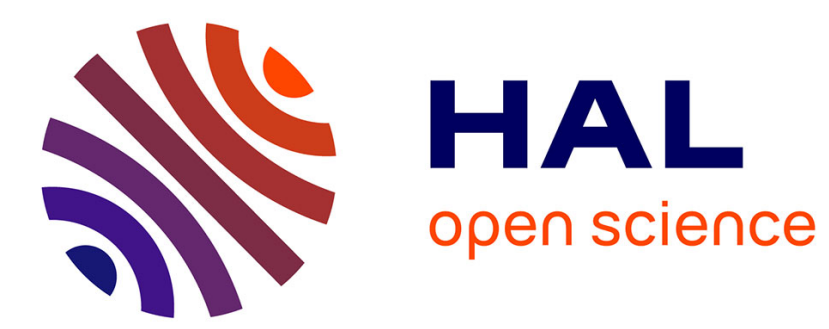

\title{
SHOCK ELECTRONS FROM ION-SOLID PENETRATION
}

H. Rothard, M. Burkhard, J. Kemmler, C. Biedermann, K. Kroneberger, P. Koschar, O. Heil, K. Groeneveld

\section{- To cite this version:}

H. Rothard, M. Burkhard, J. Kemmler, C. Biedermann, K. Kroneberger, et al.. SHOCK ELECTRONS FROM ION-SOLID PENETRATION. Journal de Physique Colloques, 1987, 48 (C9), pp.C9-211-C9214. 10.1051/jphyscol:1987932 . jpa-00227350

\section{HAL Id: jpa-00227350 https://hal.science/jpa-00227350}

Submitted on 1 Jan 1987

HAL is a multi-disciplinary open access archive for the deposit and dissemination of scientific research documents, whether they are published or not. The documents may come from teaching and research institutions in France or abroad, or from public or private research centers.
L'archive ouverte pluridisciplinaire HAL, est destinée au dépôt et à la diffusion de documents scientifiques de niveau recherche, publiés ou non, émanant des établissements d'enseignement et de recherche français ou étrangers, des laboratoires publics ou privés. 
SHOCK ELECTRONS FROM ION-SOLID PENETRATION ${ }^{(1)}$

H. ROTHARD, M. BURKHARD, J. KEMMLER, C. BIEDERMANN,

K. KRONEBERGER, P. KOSCHAR, O. HEIL and K.O. GROENEVELD

Institut für Kernphysik der Joh. Wolfg. Goethe-Universitä, August-Euler-Strasse 6, D-6000 Frankfurt-am-Main 90, F.R.G.

\section{Résumé}

Les distributions angulaires des électrons lents ( $\mathrm{E}_{\mathrm{e}}<20 \mathrm{eV}$ ) émergeant d'une cible solide lorsque elle est bombardée avec des ions rapides montrent des structures importantes qui peuvent être expliquées à l'aide de la prédiction théorique de l'émission des électrons directionels induite par des ondes de choc dans le plasma d'électrons à l'intérieur du solide. L'émission de ces électrons directionels dépend fortement de l'état de la surface de la cible.

\section{Abstract}

Angular distributions of low energy electrons $\left(\mathrm{E}_{\mathrm{e}}\langle 20 \mathrm{eV})\right.$ from ionsolid-penetration show prominent peak structures which agree in each studied detail with the predicted directed electron emission from shock waves in the electron plasma of the solid. The emission of shock electrons is strongly influenced by surface contamination and structure.

Penetrating a solid foil, a fast ion lion velocity $v_{P} \geq v_{B}$, $v_{B}=B o h r$ velocity) causes a collective response of the electron plasma, which manifests as an electron density fluctuation with axial symmetry, the dynamical polarization wake $/ 1 /$.

Experimental studies show an influence of the wake on such signals as e.g. the energy-angle distribution of fragments of coulomb-exploding molecular ions $/ 2,3 /$, on ion induced secondary electron emission $/ 4,5 /$, on the stopping power of molecular ions $/ 6 /$ and on the substate population of heavy hydrogenlike ions produced by electron capture in. solids $/ 7 /$.

The ion induced electron density fluctuations show the characteristic behaviour of Mach shock waves propagating in cones through the solid with the group velocity $v_{s}$. This has been predicted to lead to the emission of "shock electrons" in a direction perpendicular to the shock wave front $/ 8 /$. The preferential emission angle $\theta_{\text {em }}$ is given by the Mach relation $\cos \theta_{e m}=v_{s} / v_{p}$ as a function of the projectile

\footnotetext{
(1) Supported by Bundesministerium fün Forschung und Technologie BMFT Bonn, under contract number 06 OF $173 / 2$ Ti 476
} 


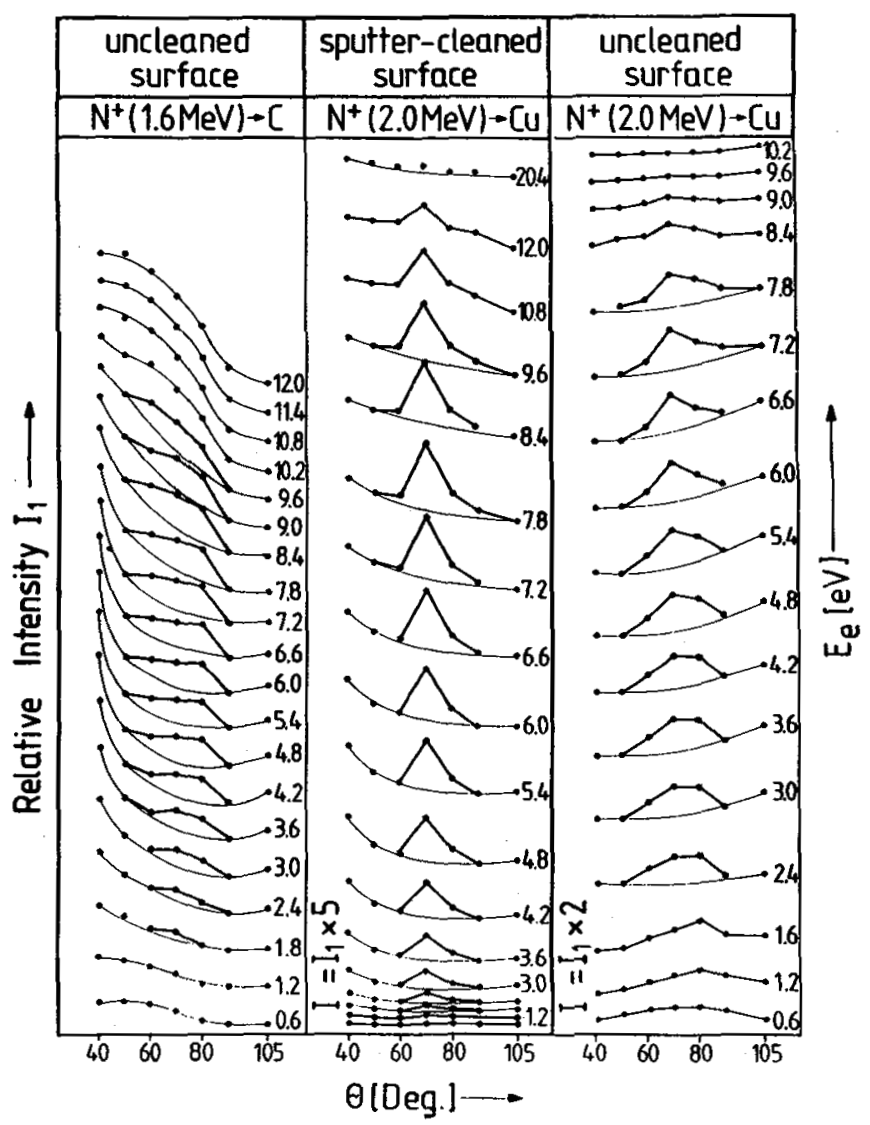

Eig.1: Angular distributions $\left(40^{\circ} \leq \Theta \leq 105^{\circ}\right.$, of low energy secondary electrons at different electron energies $0.6 \mathrm{eV} \leq \mathrm{E}_{\mathrm{e}} \leq 20.4 \mathrm{eV}$ from a Cfoil ( $d=1000 A$; left) and an uncleaned resp. sputter-cleaned cu-foil ( $d=1000 \mathrm{~A}$; centre and right) bombarded with $\mathrm{N}^{+}$(see text). Note the different intensity scales!

velocity $v_{p} / 8,9 /$. It has been proposed to detect shock electrons as peak structures in angular distributions of low energy secondary electrons emitted from thin solid foils in the forward half cone with regard to the beam direction $/ 8 /$. Recently, first evidence for the emission of shock electrons has been found /10/. Angular distributions of low energy electrons show prominent structures at electron energies $\mathrm{E}_{\mathrm{e}}<20 \mathrm{eV}$. The mean emission angle $\theta_{\text {em }}$ of electrons from these peak structures depends on the projectile velocity $v_{p}$ according to the Mach relation and the target electron density $n_{e}$ in agreement with the theoretical predictions $/ 8,10 \%$. 


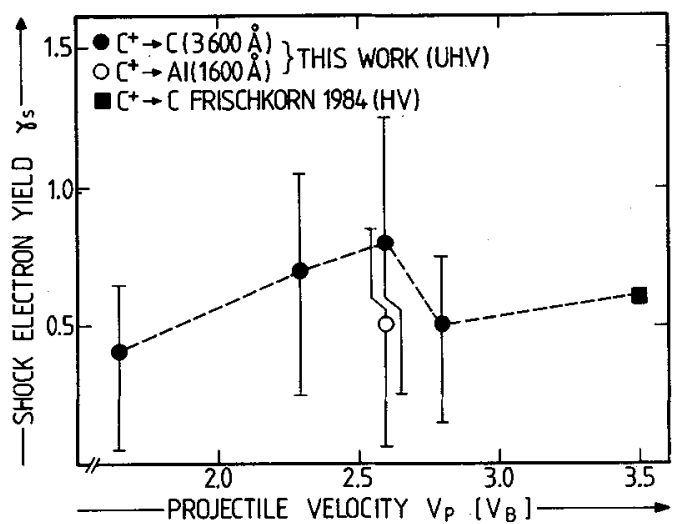

Fig.2: Number of shock electrons per incoming projectile $\Upsilon_{\mathbf{s}}$ as a function of the projectile velocity $v_{p}$.

Fig.1 gives an example of angular distributions $\left(40^{\circ} \leq \theta \leq 105^{\circ}\right)$ of low energy secondary electrons at different electron energies $0.6 \mathrm{eV} \leq \mathrm{E}_{\mathrm{e}} \leq 20.4 \mathrm{eV}$ from the collision systems $\mathrm{N}^{+}\left(\mathrm{E}_{\mathrm{P}}=1.6 \mathrm{MeV}\right)$ on C-foil $(d=1000 A)$ and $N^{+}\left(E_{P}=2.0 \mathrm{MeV}\right)$ on Cu-foil $(d=1000 \mathrm{~A})$. The digtributions have been measured under ultrahigh vacuum conditions $\left(\mathrm{p}^{* 10^{-7}} \mathrm{~Pa}\right)$ from uncleaned and sputter cleaned solid surfaces with an electrostatic electron energy analyser /11/. The surface condition of the solid foil targets has been controlled by Auger- and secondary electron spectroscopy and Rutherford forward scattering /12/. Static magnetic fields of the environment were compensated to less than 10 mGauss. In every angular distribution, a $v_{p}$-dependent peak appears at electron energies $\mathrm{E}_{\mathrm{e}}<20 \mathrm{eV}$ superimposed on the continuous secondary electron background. For electron energies $\mathrm{E}_{\mathrm{e}}>20 \mathrm{eV}$, the secondary electron intensity shows only a weak monotonic dependence on the observation angle $\theta$.

The surface structure and composition of a solid strongly influences both the total secondary electron yield /13/ and the shape of secondary electron energy distributions /13,14/, especially in the case of low energy electrons $E_{e}<20 \mathrm{eV}$. Electron emission from the single electron deexcitation of plasmons, a collective effect related to wake phenomena, is strongly dependent on surface properties, too 115/. The transmission of electrons through the surface, their energy loss and reflection at the surface strongly depend on both the surface potential barrier and the surface structure, influenced by adsorbed substances and oxides /14/. The important influence of these surface properties on shock electron emission is demonstrated in fig.1. In the case of a sputter cleaned $\left(8 \mathrm{nAmin} \mathrm{Kr}^{+}\right.$-ions of $24 \mathrm{keV} / \mathrm{u}$ specific energy) copper target, the shock electron intensity is enhanced by a factor of 3 and shows a sharper maximum at $\Theta_{\mathrm{em}} * 70^{\circ}$ over a broader range of electron energies $1 \mathrm{eV} \leq \mathrm{E}_{\mathrm{e}} \leq 20 \mathrm{eV}$ compared to an uncleaned copper target, where the shock electrons appear at lower energies $\mathrm{E}_{\mathrm{e}}<12 \mathrm{eV}$. In the case of an uncleaned copper surface, which is covered 
mainly by carbon $/ 12,14 /$, the angular distribution and the shape of the shock electron structure resemble the angular distributions from carbon targets (fig.1).

Surface diffraction and reflection phenomena, caused by the surface potential barrier and geometrical inhomogeneities leading to a broadening of the shock electron peak, are not included in recent theories $/ 8,9 /$. Surface absorption and reflection effects can also be the reason for the deviation of the theoretically calculated number of shock electrons per projectile produced inside the solid $\left(r_{\mathbf{s}} \approx 1000\right)$ from the measured number of shock electrons ejected from the surface $\left(r_{\mathrm{g}} \approx 0.7\right)$. The shock electron yield $r_{\mathrm{s}}$ is shown in fig. 2 as a function of the projectile velocity $v_{P}$ for the collision systems $C^{+}=>C$ and $\mathrm{C}^{+} \Rightarrow>\mathrm{Al}$. The $\gamma_{\mathrm{s}}$-values are only a rough estimation based on the following assumptions: 1 . The secondary electron yield in forward direction for the quoted collision systems is $r_{f} \approx 25,2$. the transmission of the spectrometer is $\mathrm{T}\left(\mathrm{E}_{\mathbf{e}}\right)=1,3$. the secondary electron intensity shows only a weak, cosine-like dependence on the observation angle $\Theta$ and $4.85 \%$ of all emitted electrons have energies less than 20 ev. This calculation leads to a surprisingly good agreement with an estimate of $\gamma_{\mathbf{s}}$ given by Frischkorn /16/ (see fig.2).

/1/ A.Mazarro,P.M.Echenique and.R.H.Ritchie Phys. Rev. B27 (1983) 4117 (and references therein)

/2/ J.Remillieux, Nucl. Instr, Meth. 170 (1980) 31

/3/ G.J.Kumbartzki,H.Neuburger,H,-P. Kohl and W.Polster Nucl. Instr. Meth. 194 (1982) 291

14/ H.J.Frischkorn, K.O.Groeneveld, P.Koschar, R. Latz and J.Schader Phys. Rev. Lett. 49 (1982) 1671

15/ H.J.Frischkorn,K.O.Groeneveld,S.Schumann, R.Latz, G.Reichhardt, J.Schader,W.Kronast and R.Mann, Phys. Lett. $76 \mathrm{~A}$ (1980) 155

16/ J.Kemmler, P.Koschar,M.Burkhard and K.O.Groeneveld Nucl. Instr. Meth. B12 (1985) 62 (and references therein)

17/ J.P.Rozet, A.Chetioui, P.Bouisset, D. Vernhet, K. Wohrer, A. Touati, C.Stephan and J.P.Grandin, Phys. Rev. Lett. $\underline{58}$ (1987) 337

18/ W.Schäfer,H.Stöcker,B.Müller and W.Greiner Z. Phys. $\underline{\text { A288 }}$ (1978) 349, Z. Phys, B36 (1980) 319

19/ D.K.Brice and P.Sigmund Mat. Phys. Medd. Dan. Vid, Selsk. $\underline{40}$ (1980) No.8

/10/ M.Burkhard, H.Rothard,C.Biedermann, J . Kemmler, K. Kroneberger, P. Koschar,O.Heil and K.O.Groeneveld,Phys. Rev. Lett. 58 (1987) 1773

/11/ W.Lotz,M.Burkhard, P.Koschar, J .Kemmler,H.Rothard, C.Biedermann, D.Hofmann and K.O.Groeneveld, Nucl. Instr. Meth. A245 (1986) 560

/12/ M.Burkhard,H.Rothard,J.Kemmler,K.Kroneberger and K.O.Groeneveld accepted by $J$. Phys. D

113/ D.Hasselkamp, S.Hippler and A.Scharmann Nucl. Instr. Meth. B1B (1987) 561 (and references therein)

114/ M.Burkhard,H.Rothard,C.Biedermann,J.Kemmler,P.Koschar and K.O.Groeneveld, Nucl. Instr. Meth. B24/25 (1987) 143

/15/ M.Burkhard,H.Rothard and K.O.Groeneveld, to be published (1987)

/16/ H.J.Frischkorn, Thesis,J.W.Goethe-Univ., Frankfurt (1984) 